INTERNATIONAL JOURNAL OF RESEARCHES IN BIOSCIENCES, AGRICULTURE AND TECHNOLOGY

(C) VISHWASHANTI MULTIPURPOSE SOCIETY (Global Peace Multipurpose Society) R. No. MH-659/13(N) www.vmsindia.org

\title{
HISTOPATHOLOGICAL ALTERATIONS IN SKIN OF THE FRESH WATER FISH, HETEROPNEUSTES FOSSILIS EXPOSED TO QUINALPHOS AND CYPERMETHRIN
}

\author{
J. S. Maske \\ Department of Zoology, Govt. Institute of Science, Nagpur-440001, Maharashtra, India. \\ jsmaske@gmail.com
}

\begin{abstract}
:
In aquatic ecosystems, pesticides enter the food chain, accumulate in non-target organisms and increase in animal tissue to alarming concentrations. They are intentionally toxic to organisms. They caused adverse impacts on aquatic fauna including fish. The present study was carried out to investigate the histopathological effects of the insecticides quinalphos and cypermethrin on skin of the fresh water fish, Heteropneustesfossilis. The fishes were exposed to the sublethal concentrations $\left(1 / 5^{\text {th }}\right.$ of $\left.96 \mathrm{hr} \mathrm{LC}_{50}\right)$ of these insecticides for 4 , 15 , and 30 days. The histopathological alterationsobserved in the skin were severe as compared to control. The changes included spaces in between the epidermal tissues, club cells reduced in numbers, mucous cells lost their identity, muscle bundles reduced in numbers, separation of dermis layer from epidermis, blood vessels damaged and blood cells came out of vessels and spreaded.The fish exposed to cypermethrin exhibited more damage in skin than those exposed to quinalphos.

Keyw ords: Histopathology, skin, Heteropneustesfossilis. quinalphos, cypermethrin.
\end{abstract}

\section{Introduction:}

Water pollution can be caused by agricultural wastes including pesticides that are washed off from the land to the aquatic system through irrigation, rainfall and leaching. Pesticides are biologically active chemicals used for killing undesirable plants or insect pests. They are intentionally toxic to undesirable aquatic organisms including fishes, they may also be toxic to desirable one including ourselves. Extensive and indiscriminate use of these pesticides leads to aquatic pollution and rendering adverse effects on fishes.

Fishes hold an important position in food chain as they provide protein rich food for human beings. Fishes are important non-target organisms which are affected in the pesticide polluted aquatic environment in nature. They could be used as indicator organisms for monitoring pollution. Hence, the fresh water fish, Heteropneustesfossilishas been included in the present piece of work. Histology is an important tool to assess the damage occurred to various organ systems and tissues at cellular level. Histopathology of vital organs of animals helps in deciding the safe level concentration of pesticide application which in turn would protect the aquatic environment and useful fauna.

The protective covering of the fish body is skin which protects the fish from injury and infections, so it was selected for the present study. An organophosphate, quinalphos and a synthetic pyrethroid, cypermethrin are widely used by farmers to save crops from insect pests. Hence, in the present investigation, efforts have been made to evaluate the toxic effects of these insecticides on skin of fish.

\section{Material and Methods:}

The fish, Heteropneustesfossilis were collected from fresh water bodies around Nagpur. Fishes were dipped in $0.1 \%$ potassium permanganate solution to avoid dermal infections. They were acclimatized for 10 days to laboratory conditions in glass aquaria filled with chlorine free water. Water quality was same as the one used in toxicity tests. Fishes were fed once a day with Tokyu pellets.

Toxicity tests were performed by using insecticides quinalphos and cypermethrin 25\% EC each as per standard methods by APHAAWWA-WPCF (1976). The fishes with total length ranging from 18.8 to $20.2 \mathrm{cms}$ and weight ranging from 40 to $60 \mathrm{gms}$ were chosen for experiments. $96 \mathrm{hr}$ LC50values were determinedby using Probit Analysis (Finney, 1971). Further, the fishes were exposed separately to sublethalconcentrons $1.267 \mathrm{mg} / 1$ and $0.056 \mathrm{mg} / 1 \quad\left(1 / 5^{\text {th }}\right.$ of $\left.96 \mathrm{hr} \quad \mathrm{LC}_{50}\right)$ of respective insecticide for 30 days. The fishes from both control and exposed groups were sacrificed at the interval of 4 days, 15 days and 30 days of exposure.

The methodology given by Humason (1979) was adopted for studying the histopathological alterations in the skin of fish. The tissues of skin were dissected out and fixed for 24 hours in aqueous Bouin's fixative. Thereafter, the tissues were thoroughly washed in running tap water for 24 hours to remove yellow colour of picric acid. Then the tissues 
were dehydrated in different grades of alcohol, cleared in xylene and embedded in paraffin wax. Paraffin blocks containing tissue were prepared and sections cut at 5-6 $\mu$ thickness. These sections were fixed on glass slides and then stained with Ehrlich's haematoxylin and counterstained with eosin. The stained sections were observed under microscope and photomicrographs were prepared by using micro imaging computerized system attached with C.C.D. camera.

\section{Results:}

\section{Histology of skin of control fish :}

The skin of $H$. fossilis is scaleless. It is a protective covering of body and has respiratory, excretory and osmoregulatory functions. Histologically the skin consists of an outer epidermis, the inner dermis separated by a basement membrane and subcutis followed by underlying muscle bundles. Epidermis is composed of several layers of flattened epidermal, mucous, club, granular and pigment cells together called epithelial cells. The flattened epidermal cells (stratified epithelium) forming superficial layer, have centrally located oval nuclei. Middle portion of epidermal layer consists of polygonal cells with nuclei. These are followed by basal layer of columnar cells of epidermis supported by a basement membrane. Cells of basal layer also called malpighian cells which multiply mitotically to give rise to new cells to replace outer worn out cells. Mucous cells are flask-shaped or spherical with short neck and crescentric nucleus. They are derived from basal layer and are distributed from base to periphery and open at the surface (exterior). These cells produce glycoprotein and mucin which forms lubricating mucus. Club-cells are spherical and quite large with centrally placed vesicular nuclei. These cells are mostly present in the middle and basal parts of epidermis. Primary function of these cells is complementary to mucous cells to protect epithelium.

Dermis of skin consists of connective tissue layer divided into stratum spongiosum and stratum compactum, subcutis, blood vessels, chromatophores (pigment cells), nerves and cutaneous sense organs. Subcutis lies below the dermis and above muscle bundles (Fig. 1 \& 2).

\section{Histopathological alterations in skin of fish} exposed to quinalphos:

4 days exposure: After 4 days exposure, the structure of fish skin revealed damage at some places. Spaces were observed between the epidermal tissues due to damage to epidermal cells. Musculature wasnot so compact and their bulk was reduced. Dermal muscle bands also lost their compactness (Fig. $3 \& 4$ ).

15 days exposure: After 15 days exposure, epidermal tissues became thinner. Cells of epidermis were flaked in its outermost part. Spaces appeared between epidermal tissues. Number of club cells was reduced in great proportion. Mucous cells also were reduced in number. Dermis layer appeared to be separated from epidermis. Muscle blocks (bundles) were reduced in numbers in the dermis, instead only muscle fibres were observed. Further damage to blood vessels was observed as blood cells appeared to ooze out of the vessels and spread (Fig. 5 \& 6).

30 days exposure: After 30 days exposure, epidermis layer wasfurther damaged. More spaces were seen in between epidermal tissues. Club cells were reduced in number in the epidermis layer. Muscle blocks in dermis were greatly reduced in number. Number of blood vessels was also reduced (Fig. $7 \& 8$ ).

Histopathological alterations in skin of fish exposed to cypermethrin:

4 days exposure: After 4 days exposure, epidermis layer of skin was broken at certain places. Spaces were found in between epidermal tissues. Mucous cells secreted more mucus and lost their identity. Club cells were swollen. Gland cells became more prominent. Musculature did not remain so compact. Dermal muscle bands appeared to fall apart or separated (Fig. 9 \& 10).

15 days exposure: After 15 days exposure, outer part of epidermal layer was damaged showing appearance of notches. At many places, spreaded up patches of club cells were observed below the outer part of epidermis. There was no compactness in epidermal tissues instead spaces were observed in it. Dermal muscle bundles were reduced in great bulk. Blood vessels weredamaged and red blood cells were seen outside the blood vessels (Fig. $11 \& 12$ ).

30 days exposure: After 30 days exposure, epidermis layer was further damaged. Club cells remain scattered and reduced in number in epidermis. Activity of mucous cells was reduced. Spaces were increased in between epidermal tissues. Blood vessels appeared to be damaged in epidermis. Muscle blocks were decreased in numbers (Fig. 13 \& 14). 

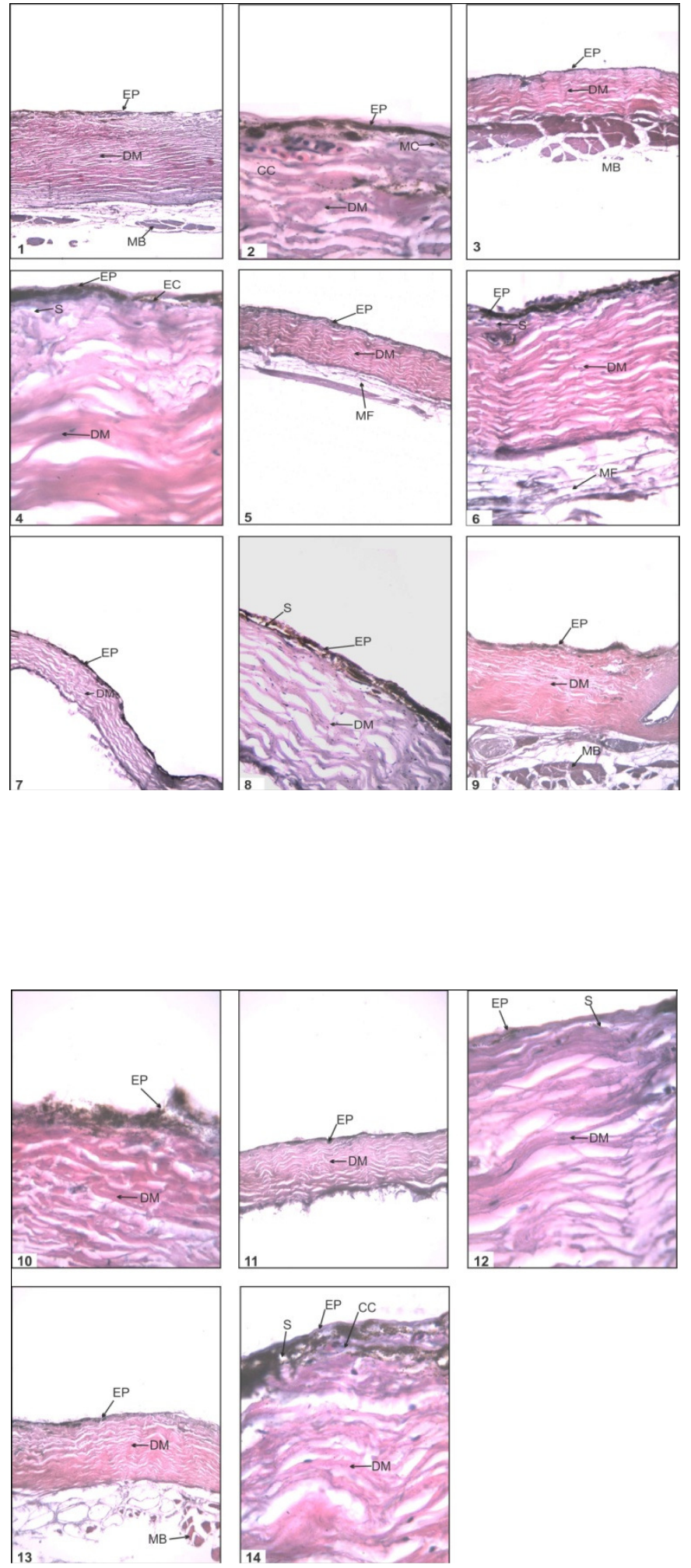

Fig. 1 \& 2: Section of skin of controlH.fossilis. (HE 100x \& 1000x respectively).

Fig.3 \& 4: Section of skin of H.fossilis exposed toQuinalphos for 4 days (HE 100x \& 1000x).

Fig.5 \& 6: Section of skin of H.fossilis exposed to Quinalphos for 15 days(HE 100x\& 400x).

Fig.7 \& 8: Section of skin of H.fossilis exposed toQuinalphos for 30 days(HE 100x\& 400x).

Fig.9\&10: Section of skin of H.fossilisexposed toCypermethrin for 4 days (HE 100x\& 1000x).

Fig.11\&12: Section of skin of H.fossilisexposed toCypermethrin for 15 days (HE 100x\& 1000x).

Fig.13\&14: Section of skin of H.fossilisexposed toCypermethrin for 30 days (HE 100x\& 1000x).

Abbreviations:EP-Epidermis, D-Dermis, MC-Mucous cell, CC-Club cells, EC-Epidermal cells, SSpaces, DM-Dermal musculature, MF-Muscle fibres, MB-Muscle bundles. 


\section{Discussion:}

Skin of fish is highly vulnerable to polluted waters. Any injury or deformity caused to skin may lead to several problems and ultimately mortality. The work on effect of pesticides on skin of fish is very much limited. Kulshrestha and Saxena (1984) noticed secretion of mucus, detachment of epidermis from dermis, vacuolation in dermis and destruction of epidermal cells in skin of Mystusvittatus on exposure to sublethal concentration of DDT. They also observed that DDT exposure caused delay in the process of regeneration of cutaneous wounds. Plaha (1988)

reported histopathological changes in skin of Heteropneustesfossilis induced by pesticides. He reported degeneration, loss of cellular differentiation in epidermis and horizontal splitting of musclefibres in dermis on exposure to malathion. On exposure to $\mathrm{BHC}$, reduction in epidermis, shrinkage of mucous cells and vacuolation in the dermis were observed, Visibility of chromatophores was more in the later stages of exposure. Gupta (1989) observed skin damage in Mystustengara on exposure to carbaryl, malathion and BHC. Vacuolation, cellular deformities, necrosis, rupture in epidermis and dermis, space formation, splitting and cellular disintegration were noticed on exposure to carbaryl. Degeneration of epidermis and disorganization were the marked changes on malathion exposure. Also chromatophores were visible on prolonged exposure to BHC. Jain (2000) observed damage to skin of Anabas tesudineus exposed to pesticides. On malathion exposure, epidermis was degenerated, mucous cells were enlarged and depleted of mucus secretion and chromatophores were greatly reduced in number. On BHC exposure, epidermis was detached, mucous cells shrunk and was less prominent and number of chromatophores was increased. On carbaryl exposure, there was no change in number of chromatophores but epidermis and dermis showed cellular disorganization.

In the present study, the skin of $H$. fossilisexposed to sublethal concentrations of quinalphos and cypermethrin showed several histopathological changes. The skin, on exposure to sublethal concentrations of both the insecticides initially at 4 days showed broken epidermis layer at some places, spaces in between epidermal tissues due to damage to epidermal cells, musculature not compact and dermal muscle bands also not compact. Further changes become more pronounced at 15 days exposure. Number of club cells and mucous cells reduced, dermis layer appears to be separated from epidermis, muscle blocks reduced in numbers in the dermis and blood vessels damaged as blood cells appear to ooze out. Further, at 30 days prolonged exposure, epidermis layer was further damaged, more spaces in between epidermal tissues, club cells remain scattered and reduced in number, activity of mucous cells was reduced, blood vessels appeared to be damaged and muscle bundles in dermis weregreatly reduced in number. Similar changes have been reported in the skin of fish by Kulshrestha and Saxena (1984), Plaha (1988), Gupta (1989) and Jain (2000). It has been noticed that in $H$. fossilis exposed to cypermethrin, the skin exhibited more damage than those exposed to quinalphos. This indicates higher toxicity of cypermethrin.

\section{Acknowledgement:}

Author is thankful to the Director, Govt. Institute of Science, Nagpur and the Head, Department of Zoology for providing laboratory facilities.

\section{References:}

APHA, AWWA and WPCF (1976): Bioassay methods for aquatic organisms. In: Standard methods for the examination of water and wastewater, 14th edition. American Public Health Association, Washington, DC, 685-743.

Finney, D.J. (1971): Probit Analysis. 3rd edition. Cambridge University Press, London, (England).

Gupta, R. (1989): Effect of some pesticides on the brain and some tissues of fish. Ph.D. Thesis, Dr. H.S. Gour University, Sagar (M.P.).

Humason, G.L. (1979): Animal tissue techniques. W.H. Freeman and Company, San Francisco, 1-661.

Jain, G. (2000): Pesticides and Fish. Aditya Publishers, Bina (M.P.).

Kulshrestha, S.K. and Arora, N. (1984): Effect of sublethal doses of carbaryl and endosulfan on the skin of Channastriatus (Bloch). J. Environ. Biol., 5(3), 141-147.

Kulshrestha, S.K. and Saxena, M. (1984): Toxic effects of sublethal doses of DDT on the skin of freshwater teleost, Mystusvittatus. Proc. Sem. Eff. Ag. Fau., 51-54.

Lonkar, A.N. (1996): Observation on the toxic effects of some insecticides on selected 
freshwater animals. Ph.D. Thesis, Nagpur University, Nagpur.

Maske, J.S. and Thosar, M.R. (2012): Independent and Joint Toxicity of few Insecticides on Fresh water Catfish,
Heteropneustesfossilis. Bionano Frontier, Spl. Issue 5(2-I), 127-129.

Plaha, R. (1988): Pesticide induced effects in some tissues of a teleost fish. Ph.D. Thesis, Dr. H.S. Gour University, Sagar, M.P. 